in a state of flux. With the post-war energetic enforcement of antitrust by the Department of Justice, the Supreme Court in cases such as Isbrandtsen and R.C.A. has appeared to shy away from the agencies in matters relating to antitrust. A related tendency is the resolution of formerly divergent regulatory and antitrust policies in favor of the policy of greater competition via the road of judicial review. ${ }^{127}$ Also, a growing antipathy by the Supreme Court to exclusive arrangements has been evident. ${ }^{128}$ One must admit the present primacy of antitrust over regulation. But to the extent that the Court is willing to overturn former precedents, primary jurisdiction in antitrust suits will be a rapidly changing doctrine. This may be especially true in the shipping industry where regulation by the Maritime Board has had its strongest hold.

${ }^{127}$ E.g., United States v. R.C.A., 358 U.S. 334 (1959).

${ }^{128}$ E.g., Northern Pacific Ry. Co. v. United States, 256 U.S. 1 (1958); Denver Union Stock Yard Co. v. Producers Livestock Marketing Ass'n, 356 U.S. 282 (1958); Standard Oil Co. of California v. United States, 337 U.S. 293 (1949).

\title{
AN ATTORNEY GENERAL'S STANDING BEFORE THE SUPREME COURT TO ATTACK THE CONSTITUTIONALITY OF LEGISLATION
}

The Supreme Court has often invoked the rule that a public official has no standing to attack the constitutionality of legislation which he is charged with enforcing. ${ }^{1}$ While this general rule appears well established, it is not clear whether an attorney general, as contrasted with other public officials, is in all cases within the scope of the rule. This issue was raised, but not reached, during the Court's 1958 term in Alaska v. American Can Co., in which the Alaska Attorney;General attacked the constitutionality of an Alaska statute as construed by the lower courts. ${ }^{3}$ The purpose of this comment is to examine this question and see in what situations, if any, an attorney general, state or federal, should have standing before the Supreme Court to challenge the constitutionality of legislation of his own jurisdiction. ${ }^{4}$

${ }^{1}$ Stewart v. Kansas City, 239 U.S. 14 (1915); Braxton County Court v. West Virginia, 208 U.S. 192 (1908); Smith v. Indiana, 191 U.S. 138 (1903); Caffery v. Oklahoma Territory, 177 U.S. 346 (1900). See also, the separate opinion of Justice Frankfurter in Coleman v. Miller, 307 U.S. 433, 460 (1939); The Power of a State Officer to Raise a Constitutional Question, 33 Col. L. Rev. 1036 (1933).

\section{U.S. 224 (1959).}

${ }^{3}$ Brief for Petitioner at 11.

"The scope of this comment is limited to those cases where an attorney general attacks acts of his own legislature. It is a quite different question, and well settled, that an attorney general, in the name of his government, may question the constitutionality of legislation of another government. See United States v. Standard Oil Co. of California, 21 F.Supp. 645 (S.D.Cal., 1937) (federal versus state legislation); Ohio v. West Virginia, 262 U.S. 553 (1923) (state versus another state's legislation); Hopkins Savings Ass'n v. Cleary, 296 U.S. 315 (1935) (state versus federal legislation); cf. Massachusetts v. Mellon, 262 U.S. 447 (1923). 
It appears that the cases establishing the general rule are applicable only to minor officials. In Smith v. Indiana, ${ }^{5}$ the leading example of these cases, the constitutional issue was raised by a county official as a defense to a mandamus action brought by the state attorney general on the relation of a taxpayer. In dismissing the official's appeal, the Supreme Court stated that he did not have the personal interest which the Court requires for standing to question the constitutionality of a statute. ${ }^{6}$ If lack of personal interest were the sole ground for denying standing to the officials in cases like the Smith case, there would then appear to be no question that an attorney general would likewise be included within the general rule denying standing. But the Supreme Court in the few cases that have presented the issues of an attorney general's standing has allowed the United States Attorney General to dispute the constitutionality of federal legislation. ${ }^{7}$ Since the Court has apparently distinguished between an attorney general and other public officials, the denial of standing would therefore seem to have turned on grounds other than the lack of personal interest.

Since a public official has a legal duty to enforce the mandates of his legislature, ${ }^{8}$ it is understandable that the Supreme Court may think it unseemly for a public officer, particularly a minor official, to make a personal judgment as to the constitutionality of a statute which the officer is charged with enforcing. ${ }^{9}$

${ }^{s} 191$ U.S. 138 (1903). The other cases in this line, cited note 1 supra, are almost identical with Smith v. Indiana. Where the official was respondent, compare Columbus \& Greenville Ry. v. Miller, 283 U.S. 96 (1931), with Huntington v. Worthen, 120 U.S. 97 (1887). See note 36 infra.

6 This requirement of personal interest is a facet of the Supreme Court's doctrine of standing, developed on its own initiative to avoid passing on constitutional questions until the complaints of a party who has been substantially injured make it absolutely necessary. See the concurring opinion of Justice Brandeis in Ashwander v. Tennessee Valley Authority, 297 U.S. 288,341 (1936). This doctrine, though closely related, is distinct from the constitutional requirement that the Court entertain only a case or controversy. For a thorough discussion of this distinction, see Rescue Army v. Municipal Court, 331 U.S. 549, 568-70 (1947); 3 Davis, Administrative Law Treatise \$22.04 (1958). infra.

7 E.g., United States v. Realty Company, 163 U.S. 427 (1896), discussed in text at note 36

${ }^{8}$ The Court's recognition of this legal duty of an official has led it to grant standing to a public official where he seeks to uphold the validity of legislation which the state court has held unconstitutional. See, e.g., State Tax Comm'n v. Aldrich, 316 U.S. 174 (1942). For the earlier rule, see Marshall v. Dye, 231 U.S. 250 (1913).

9 "One who is merely the self-constituted spokesman of a constitutional point of view can not ask us to pass on it." Coleman v. Miller, 307 U.S. 433, 467 (1939) (concurring opinion). A significant factor in the Smith v. Indiana line of cases, see note 1 supra, is that the state attorney general was opposing the minor official. Compare the dictum in Columbus \& Greenville Ry. v. Miller, 283 U.S. 96 (1931), a case in which the state attorney general apparently took no part, with Huntington v. Worthen, 120 U.S. 97 (1887), where the state attorney general agreed with the official. On the other hand, the state courts have been quite liberal in permitting a minor official to question the constitutionality of state legislation. For a discussion of some of these cases, see The Power of a State Officer to Raise a Constitutional Question, 33 Col. L. Rev. 1036 (1933). That the Supreme Court would not be bound by a state court's 
The reasoning in the cases denying standing to a municipality to attack the constitutionality of state legislation on the theory that the municipality is a mere agent of the state is support for the denial of standing to a minor public official. ${ }^{10}$ But in contrast to the relatively narrow segments of a government which most public officers represent, an attorney general is the chief legal officer of his government, ${ }^{11}$ and although at times he acts for the executive branch alone, ${ }^{12}$ his primary function is to represent the interests of the government as a whole. ${ }^{13}$ The traditional common-law view of an attorney general's broad discretion and power are reflected in the federal and most of the state statutes prescribing his duties: ${ }^{14}$ "[the federal law] does not direct how he shall participate in such cases; it gives him broad, general powers intended to safeguard the interests of the United States in any case, and in any court of the United States, whenever in his opinion those interests may be jeopardized." 15

Since an attorney general represents the overall interests of his government, he has been permitted to attack the actions of agencies of the government which in his opinion jeopardize these overall interests. ${ }^{16}$ For example, in United States v. Interstate Commerce Commission, ${ }^{17}$ the Attorney General, representing the United States as a substantial shipper of goods, was allowed to appeal an ICC order dismissing a claim of the United States. ${ }^{18}$ However, the right to

recognition of a party's interest was established in Tyler $\mathbf{v}$. Judges of Court of Registration, 179 U.S. 405 (1900); cf. the dissenting opinion of Justice Douglas in Doremus v. Board of Education, 342 U.S. 429, 435 (1952). Nor probably would the Erie doctrine apply to these rules relating to standing. See Rescue Army v. Municipal Court, 331 U.S. 549, 570 (1947).

${ }^{10}$ See, e.g., Pawhuska v. Pawhuska Oil Co., 250 U.S. 394 (1919). Consult Robertson and Kirkham, Jurisdiction of the Supreme Court of the United States $\$ 301$ (Wolfson and Kurland ed., 1951).

11 For a general discussion of the organization and duties of the Office of the United States Attorney General, see Cummings and McFarland, Federal Justice 486 et seq. (1937).

12 See Myers v. United States, 272 U.S. 52 (1926), discussed in text at note 34 infra.

${ }^{13}$ See discussion in United States v. San Jacinto Tin Co., 125 U.S. 273, 284 (1888).

14 Federal law provides that the United States Attorney General "may, whenever he deems it for the interest of the United States . . . conduct and argue any case in any court of the United States in which the United States is interested. . . " 45 Stat. 54 (1928), 5 U.S.C. $\$ 309$ (1953). Most states have comparable legislation. See, e.g., Wis. Stat. Ann. (1957) \$14.53; cf. the Arizona provisions discussed in Shute v. Frohmiller, 53 Ariz. 483, 90 P.2d 998 (1939). For discussion of the traditional common-law duties of the attorney general, see Commonwealth v. Margiotti, 325 Pa. 17, 188 Atl. 524 (1936); Bellot, The Origin of the Attorney General, 25 L. Q. Rev. 400 (1909).

${ }^{15}$ Booth v. Fletcher, 101 F.2d 676, 681-82 (App.D.C., 1938).

16 For a concise presentation of these various situations, see Stern, "Inconsistency" in Government Litigation, 64 Harv. L. Rev. 759 (1951).

${ }^{17} 337$ U.S. 426 (1949).

${ }^{18}$ See also United States ex rel. Chapman v. Federal Power Comm'n, 345 U.S. 153 (1953), where the Secretary of the Interior was permitted to challenge an order of the FCC. It would seem that ordinarily the Court would not permit an official other than the Attorney General 
challenge the legality of the actions of an independent agency is a question significantly different from that whether an attorney general may assail the constitutionality of a statute passed by his legislature. ${ }^{19}$ The acts of an elected body of legislators should generally be treated as co-extensive with the best interests of the government, and even if an attorney general has personal doubts as to the validity of a statute, his duties seem to require that he enforce the statute until it is repealed or successfully challenged by those who are personally injured by it. ${ }^{20}$ However, the American Can Co. case and other decisions illustrate exceptional situations where it would seem quite reasonable for the Supreme Court to permit an attorney general to question the constitutionality of acts of his own legislature. These situations fall into two categories.

The first category includes those suits, already properly in court, in which an attorney general, seeking to uphold the validity of a statute, argues that the particular construction urged by his opponent would render the statute unconstitutional. An illustration of this situation is furnished by the American Can

to question the orders of other agencies of the government; the Attorney General actually initiated this suit. See Lee v. Civil Aeronautics Board, 225 F.2d 950 (App.D.C., 1955), where, in a suit in which the Attorney General did not appear, a federal officer was denied standing.

${ }^{19}$ The Supreme Court has never passed upon the standing of a state attorney general to question upon appeal the constitutionality of state legislation. While it might be argued that a state attorney general should be satisfied with the state courts to which he has access and that the Supreme Court would hesitate to assume the extra burden of passing upon these conflicts between state attorneys general and state legislatures, this comment has assumed that in regard to questions arising under the United States Constitution the Court would extend the same privileges to the United States Attorney General and to state attorneys general with similar statutory duties. However, since the analysis of this comment has limited the right of an attorney general to challenge the constitutionality of legislation to those instances in which no private party has such a right, a state attorney general would seldom be able to exercise this right. See note 31 infra. It is interesting to note that the Alaska statutes provide that "[w] henever the constitutionality or validity of any statute is seriously in doubt, and the enforcement of such statute affects the Territory ... suits or actions may by the Attorney General be instituted in the name of the Territory in any court to determine the constitutionality or validity of such law." Alaska Comp. L. Ann. (1949) \$9-1-8. It is improbable that the Supreme Court would recognize a state or territorial statute as determinative of standing before that Court. See note 9 supra. On the other hand, as long as a case or controversy is present, Congress may confer standing on a party who would not have the right but for the legislative grant. See Federal Communications Commission v. Sanders Radio Station, 309 U.S. 470 (1940). Of course, if under the Alaska statute there was a question of the personal liability of the Attorney General for nonperformance of his duties or for enforcement of an unconstitutional act, then his official interest would be supplanted by the personal one. See Ex parte LaPrade, 289 U.S. 444 (1933); First Federal Savings \& Loan Ass'n v. Loomis, 97 F.2d 831 (C.A.7th, 1938). But see, Yaselli v. Goff, 12 F.2d 396 (C.A.2d, 1926).

${ }^{20} \mathrm{It}$ appears that opinions by the United States Attorney General on the constitutionality of acts of Congress are rare. Cummings and McFarland, op. cit. supra note 11, at 515. Several state courts have granted standing to minor public officials where they have been advised by the state attorney general of the unconstitutionality of the legislation which the official is attacking. See, e.g., State ex rel. Johnson v. Baker, 74 N.D. 244, 21 N.W.2d 355 (1945). It is suggested that in such instances the Supreme Court would require the attorney general himself to raise the constitutional issue. 
Co. case itself, where the Alaska Attorney General brought a suit to collect taxes accrued under a recently repealed act on the grounds that the taxes accrued before repeal were preserved. Both the district court ${ }^{21}$ and court of appeals, ${ }^{22}$ however, construed the repealing act to exempt the defendants from liability. Believing that the statute as construed would discriminate unconstitutionally against taxpayers still liable for accrued taxes, and recognizing that the Territory would be deprived of tax revenue, the Attomey General, upon appeal to the Supreme Court, raised the question of the constitutionality of the act as construed..$^{23}$ The Supreme Court's adoption of the Attorney General's interpretation of the statute made it unnecessary for the Court to reach the constitutional issue. In such a situation, unlike that presented in Smith v. Indiana, there is no issue as to the attorney general's standing as a party to the action, either commencing or defending the suit at the trial or appellate level..$^{24}$ The issue is whether in a suit properly commenced an attorney general may call the Court's attention to the constitutional problems presented by his opponent's or a lower court's construction of the statute. It is clear that if a statute can reasonably be interpreted in two ways, the Court will adopt the construction that will maintain the act's constitutionality. ${ }^{25} \mathrm{It}$ seems unquestionable that an attorney general, in an effort to have the statute upheld, may raise the issue of the constitutionality of alternative constructions which the Court is considering.

The second category presents a situation in which an attorney general's right to appear before the Court is dependent entirely upon his standing to attack the constitutionality of legislation. For example, if the Alaska statute was susceptible to only one interpretation and the attorney general initiated his suit for taxes, his sole ground would be that the statute was unconstitutional. ${ }^{26}$

21137 F.Supp. 181 (D.Alaska, 1956). $\quad 2246$ F.2d 493 (C.A.9th, 1957).

${ }^{23}$ Brief for Petitioner at 11 . The constitutional issue had not been raised in either of the lower courts.

${ }^{24}$ This distinction was recognized, though not clearly articulated, in Barrows v. Jackson, 346 U.S. 249 (1953), where the respondent, in a suit for breach of a restrictive covenant, raised the constitutional problem that would be encountered if the Court enforced the covenant. Here there was no question of the respondent's standing before the Court; rather, the issue was whether the respondent could raise the particular constitutional argument. The Court stated: ".. we believe the reasons which underlie our rule denying standing to raise another's rights, which is only a rule of practice, are outweighed by the need to protect the fundamental rights which would be denied by permitting the damages action to be maintained." Id., at 257. See 3 Davis, op. cit. supra note 6, at \$22.07.

${ }^{25}$ See e.g., Texas v. Eastern Texas R. R. Co., 258 U.S. 204 (1922).

${ }_{26}$ Note the distinction which exists between these two categories. Under the first category, if a statute was susceptible to two constructions, one constitutional and the other not, an attorney general could bring an action under the one and attack the validity of the other. But just how reasonable does the attorney general's alternative interpretation have to be? It would appear that it would have to fall somewhere within the ambit of what the legislature intended to accomplish by that statute. This is in effect a facet of the problem of separability. See Stern, Separability and Separability Clauses in the Supreme Court, 51 Harv. L. Rev. 76 (1937). 
Hence, the question squarely presented is whether an attorney general, believing legislation to violate the Constitution and to affect adversely the best interests of his government, should be granted standing to challenge the constitutionality of that legislation. ${ }^{27}$

The Supreme Court has a well-established aversion to passing on the constitutionality of legislation until a party shows a substantial personal injury resulting from the legislation $;^{28}$ and therefore, it seems undesirable, as well as inconsistent with an attorney general's duties, to allow him standing in situations where private interests are sufficiently affected by legislation to permit them to attack its constitutionality. ${ }^{29}$ An attorney general, believing it would be in the best interests of the government to obtain a judicial determination of the validity of doubtful legislation, may usually do so by bringing a test suit

${ }^{27}$ The state courts have generally permitted state attorneys general to attack directly the constitutionality of state legislation, either by an action against those expressly within the statutory exemptions, e.g., Carroll v. Socony-Vacuum Oil Co., 136 Conn. 49, 68 A.2d 299 (1949) (state attorney general permitted to sue gas dealers for taxes collected for the state and to attack constitutionality of statute which specifically authorized dealers to retain the receipts), or by a suit to enjoin a public official from executing a law which the attorney general challenges as unconstitutional, e.g., Wilentz V. Henrickson, 133 N.J.Eq. 447, 33 A.2d 366 (1943); State ex rel. Attorney General v. Cunningham, 81 Wis. 440, 51 N.W. 724 (1892). See also, State ex rel. Davis v. Love, 99 Fla. 333, 126 So. 374 (1930); cf. State ex rel. Watson v. Kirkham, 158 Fla. 11, 27 So.2d 610 (1946). Those state decisions which have denied an attorney general standing have been based on the lack of a case or controversy, e.g., State v. Board of Supervisors, 228 La. 951, 84 So.2d 597 (1955), or the lack of any showing of an injury to the state, e.g., Albrethsen v. State, 60 Idaho 715, 96 P.2d 437 (1939).

The California case of People v. Building Maintenance Contractors' Ass'n, 41 Cal.2d 719, 264 P.2d 31 (1953), presents an interesting situation which falls somewhere between the first and second categories. There the state attorney general, in a suit to enjoin the defendants from violating the state's antitrust code, challenged the proviso which the defendants argued exempted their activities from the code's provisions, as being unconstitutionally vague. Upholding the right of the attorney general to raise the constitutional issue, the court reasoned that "[i]f the state could not attack the amendment on the ground that it is unconstitutionally vague, it would remain a part of the statutory standard of conduct, and the resulting uncertainty would necessitate invalidating the entire statute." Id., at 726 and 36 . Here the attorney general is properly before the court on other than constitutional grounds and is raising the validity of the proviso in order that the principal portion of the statute might be preserved. On the other hand, the attorney general was not merely arguing against a doubtful construction of the act as in the first category, but is attacking a specific portion of the statute. It is suggested that if this were a criminal prosecution there would be serious due process problems presented. It would seem that the government should be estopped from initiating such suits where criminal liability is premised on the state's attack of a provision of a statute upon which the defendant has relied. For similar situations, see Copeland v. State, 76 So.2d 137 (Fla., 1954); State ex rel. Landis v. S. H. Kress \& Co., 115 Fla. 189, 155 So. 823 (1934); State ex rel. Evans v. Brotherhood of Friends, 41 Wash.2d 133, 247 P.2d 787 (1952). See also, State v. Washburn, 177 La. 27, 147 So. 489 (1933); cf. Greenaway's Case, 319 Mass. 121, 65 N.E.2d 16 (1946).

${ }^{28}$ See e.g., Alabama Power Co. v. Ickes, 302 U.S. 464 (1938).

${ }^{29}$ The Supreme Court's general rule is that a party may not assert the constitutional rights of another. See e.g., Tileston v. Ullman, 318 U.S. 44 (1943). But an exception has apparently been well established by the decision in Pierce v. Society of Sisters, 268 U.S. 510 (1925), where a party who was substantially injured by a statute was permitted to invoke the constitutional rights of others to attack it. 
against a party who is personally affected by the enforcement of that legislation. ${ }^{30}$ However, there are areas of legislation which exceed the powers of the legislature and yet, because no particular private interests sustain sufficient personal injury, are not subject to judicial review. To a large extent the existence of such legislation is due to the Supreme Court's doctrines of standing, "developed, for its own governance in the cases confessedly within its jurisdiction, [to avoid] passing upon a large part of all the constitutional questions pressed upon it for decision." 31 Thus, the Court has held that neither a federal taxpayer ${ }^{32}$ nor one who suffers a mere competitive disadvantage ${ }^{33}$ has sufficient personal interest to enable him to attack federal enactments. As a result, there is an area of legislation, notably spending legislation, which is in effect unreviewable by the federal courts. The issue then is whether an attorney general may assert a constitutional argument which, due to the rules of standing, is not available to others, so as to challenge legistation which he considers to be detrimental to the interests of his government. Myers ข. United States ${ }^{34}$ demonstrates that the Court will permit the United States Attorney General to invoke the Constitution when the legislation is alleged to restrict the constitutional powers of the executive department. In the Myers case the Attorney General, opposing a suit for wages by a postmaster removed from office by the President without the consent of Congress, argued that the act requiring such consent was an unconstitutional restriction on the powers of the President. ${ }^{35}$ In this case the Attorney General, rather than representing the overall interests of the government, was appearing solely on behalf of the executive branch. If the Attorney General had accepted the validity of the statute he would in effect be opposing the President. In these circumstances the Attorney General being responsible to, as well as appointed by, the President, would be expected to take

${ }^{30}$ For an extremely interesting discussion of the government test case, see Freund, On Understanding the Supreme Court 99 et seg. (1949).

31 Concurring opinion of Justice Brandeis in Ashwander v. Tennessee Valley Authority, 297 U.S. 288, 346 (1936). See note 6 supra.

${ }^{32}$ Frothingham v. Mellon, 262 U.S. 447 (1923). It would seem that since state taxpayers have been allowed standing to attack state legislation before the Supreme Court, e.g., Wieman v. Updegraff, 344 U.S. 183 (1952), the right of a state attorney genal to attack state legislation before the Court would be limited to those relatively few instances in which state taxpayers are not recognized as having sustained sufficient injury. See Bull v. Stichman, 273 App.Div. 311, 75 N.Y.S.2d 278 (1948), aff'd 298 N.Y. 516, 80 N.E.2d 661 (1949). Alaska taxpayers, whose only courts were those of the frederal system, have been denied standing to attack territorial legislation. Sheldon v. Griffin, 174 F.2d 382 (C.A.9th, 1949).

${ }^{33}$ E.g., Hines Trustees v. United States, 263 U.S. 143 (1924); see also, Kerfoot v. Farmers' and Merchants' Bank, 218 U.S. 281 (1910). But see Chicago v. Atchison, T. \& S. F. R. Co., 357 U.S. 77 (1958).

34272 U.S. 52 (1926). Note the Brief for the United States, id., at 98.

${ }^{25}$ See also Humphrey's Executor v. United States, 295 U.S. 602 (1935). Note the Brief for the United States, id., at 616. 
a position in support of the President's action even though contrary to that of Congress. It would appear that the importance of the question of the constitutional division of powers between the executive and legislative branches, together with the improbability of any personal rights being sufficiently affected, were very significant factors in influencing the Court to permit the Attorney General to argue against the statute in the Myers case.

Another decision, United States \%. Realty Company, ${ }^{36}$ indicates that the Court considers the standing of the Attorney General to challenge legislation to extend beyond the comparatively narrow circumstances of the Myers case. Here, in a suit against the government for a grant of money authorized by special legislation, the Court, without discussion, allowed the Attorney General to defend against the claim on the sole ground that the special legislation, by providing for the payment in satisfaction of a mere moral obligation, was an unconstitutional exercise of Congress' discretion. While in the Myers case the Attorney General was arguing in support of the constitutional powers of the President, in the Realty Company case the Attorney General, besides serving the best interests of the government as a whole, was also representing the interests of federal taxpayers. The improbability ${ }^{37}$ of a taxpayer's challenging this legislation might well have been an important factor to the Court in the Realty Company case. The present impossibility of a federal taxpayer having standing would clearly present such a situation where the constitutional issue could be raised only by the Attorney General. ${ }^{38}$ In such a situation the basic constitutional principle that the judiciary is to serve as a check on the legislature would be avoided unless the Attorney General is granted standing to present the constitutional question concerning legislation which seriously jeopardizes the interests of the government as a whole. Those cases where the government sustains no injury and private interests are not sufficiently affected would in most

36163 U.S. 427 (1896). Note that the Attorney General would probably attack legislation only in those instances where it passed over the veto of the President, or perhaps, where the President signed with protest. See also, Pope v. United States, 323 U.S. 1 (1944), where the Attorney General, as respondent, argued that special legislation was invalid for altering an opinion of the Court of Claims. Brief for the United States at 18, 23. Raising the constitutional issue by a respondent would place the case in the first category in that the case is already properly before the court. See Columbus \& Greenville Ry. v. Miller, 283 U.S. 96 (1931).

${ }^{37}$ Apparently, at the time of this case federal taxpayers were permitted to attack the constitutionality of federal legislation. See Bradfield v. Roberts, 175 U.S. 291 (1899).

${ }^{38}$ This notion of an attorney general being able to gain standing concerning matters in which no one citizen has any special interest other than that which is common to citizens in general has been the basis for several state court decisions which have permitted an attorney general to challenge legislation. See, e.g., State ex rel. Attorney General v. Cunningham, 81 Wis. 440, 51 N.W. 724 (1892). The Supreme Court, in United States v. San Jacinto Tin Co., 125 U.S. 273,286 (1888), a suit by the Attorney General to void a land patent, stated that a suit by him must fail if it appears that the suit was brought solely for the benefit of some third person or no obligation existed to the general public. See also, United States ex rel. Miles Planting \& Mfg. Co. v. Carlisle, 5 App.D.C. 138 (1895); King County v. Seattle School Dist. No. 1, 278 Fed. 46 (C.A.9th, 1922). 
instances appear to fall within the class of "political questions" which the Court has deemed inappropriate for judicial consideration. ${ }^{39}$

As the right of an attomey general to question the validity of legislation has been predicated on the proposition that there ought to be someone who can challenge legislation which is detrimental to government interests, a question arises as to the propriety of an attorney general being permitted to intervene to supplement one of the parties' argument against the constitutionality of a statute. ${ }^{40}$ While it may be argued that an attorney general might be able to present a better argument than a private litigant, ${ }^{41}$ it would seem that once those who have been personally injured have gained standing to question the statute's validity, it would be inappropriate to allow the attorney general to argue against the mandates of the legislature. In the only Supreme Court case which has presented this situation, United States v. Lovett, ${ }^{42}$ government employees sued for wages which had been terminated by Congress on the ground of their being security risks. The Attorney General, refusing to defend the suit ${ }^{43}$ and thus making it necessary for Congress to hire special counsel, was permitted to join the employees' argument against the constitutionality of the Act. Under the analysis above, it would seem that the Court erred in granting standing to the Attorney'General in this case.

Thus, while it appears rather anomalous that an attorney general, whose duty it is to enforce legislation, be allowed to attack its constitutionality, it can be (1939).

${ }^{39}$ See, e.g., Colegrove v. Green, 328 U.S. 549 (1946); cf. Coleman v. Miller, 307 U.S. 433

${ }^{40}$ The federal statute provides that "[i]n any action ... to to which the United States ... is not a party, wherein the constitutionality of any Act of Congress affecting public interest is drawn in question, the court . . . shall permit the United States to intervene . . . for agument on the question of constitutionality." 62 Stat. 971 (1948), 28 U.S.C.A. $\$ 2403$ (1950). It is questionable whether Congress intended this language to confer upon the Attorney General the right to argue against the constitutionality of an act. Cf. N.Y. Executive Law (McKinney, 1951) $\$ 71$, where it is expressly provided that the attorney general may intervene only to argue in support of the constitutionality of legislation.

41 The right of the Attorney General to intervene to argue in support of the constitutionality of legislation to a large extent would seem to be based on the desire of Congress to present to the courts the fullest arguments in favor of its enactments. To use the same reasoning in regard to an argument against the constitutionality of an act would not seem to persuasive.

42328 U.S. 303 (1946).

${ }^{43}$ In regard to the pending suit by the government employees, the Attorney General, in a communique to Congress, stated: " . . . my position concurs with the President's. . . . It is at odds with the position of the Congress. In these circumstances I feel that Congress should be afforded an opportunity to be represented by their own counsel . . . to file a brief and argue on behalf of the position of Congress. ... I find it impossible to advocate with conviction the views of the Congress." H. R. Rep. No. 1117, 78th Cong. 2d Sess. 3 (1944). Although the Court found it unnecessary to utilize it, one of the Attorney General's arguments was that the statute unconstitutionally restricted the executive powers of the President, and thus was similar to his position in Myers v. United States, 272 U.S. 52 (1926). The analysis of the circumstances in the Myers case would seem to lend justification to the refusal of the Attorney General to defend the suit, but not necessarily to his right to intervene. 
seen that there are circumstances where it is not unreasonable. In the first of the two suggested categories, the attorney general was in effect seeking to uphold the validity of a statute by urging the unconstitutionality of alternative interpretations. In the second, decisions of the Supreme Court indicate quite clearly a willingness to allow an attorney general-where private persons could not- to invoke the Constitution to attack legislation which he believes seriously impairs the best interests of the government. As the cases in this area have been, and undoubtedly will be, very limited in number, the exact extent of this right of an attorney general will probably not be fuily developed. It would seem, however, that the Court would have experienced no difficulty in granting standing to the Alaska Attorney General to argue the unreached constitutional issue in the American Can Co. case.

\section{FULL FAITH AND CREDIT TO FOREIGN INJUNCTIONS}

It is not unusual for a court of general jurisdiction in one state $\left(F_{1}\right)^{1}$ having jurisdiction of the parties residing therein, to enjoin one of them (A) from suing the other $(B)$ in the courts of a sister state $\left(F_{2}\right){ }^{2}$ Typically, however, a court of $F_{1}$ will restrain $A$ from suing $B$ in the courts of $F_{2}$ only in the following cases: where the action in $\mathrm{F}_{2}$ would evade the exemption laws of $\mathrm{F}_{1} ;^{3}$ where it was

1 For the sake of clarity $F_{1}$ shall be used throughout this comment to signify the enjoining jurisdiction, and $\mathrm{F}_{2}$ shall represent the jurisdiction wherein the prosecution has been enjoined. The letters $A$ and $B$ shall stand for the enjoined and enjoining parties respectively.

2 E.g., Cole v. Cunningham, 133 U.S. 107 (1890); Weaver v. Alabama Great So. R. Co., 200 Ala. 432, 76 So. 364 (1917); Morgan v. Amick, 102 Ind. App. 603, 4 N.E.2d 51 (1936); Natalbany Lumber Co. v. McGraw, 188 La. 863, 178 So. 377 (1938). English courts have enjoined residents from suing in foreign jurisdictions on numerous occasions, see Ellerman Lines v. Read [1928] 2 K.B. 144; Portarlington v. Soulby, 3 My. \& K. 104 (1834); Harrison v. Gurney, 2 Jac. \& W. 563 (Ch., 1821). In regard to injunctions issuing against FELA suits in state or federal courts of other states, see Pope v. Atlantic Coast Line R. Co., 345 U.S. 379 (1953); Miles v. Illinois Central R. Co., 315 U.S. 698 (1942); Baltimore \& Ohio R. Co. v. Kepner, 314 U.S. 44 (1941). Concerning injunctions by federal courts against state proceedings, see 62 Stat. 968 (1948), 28 U.S.C.A. \$2283 (1950).

${ }^{3}$ Many states will enjoin the prosecution of an action in a sister state, where that suit was brought to evade a protection afforded the law defendant by the enjoining state's law. See Dehon v. Foster, 86 Mass. (4 Allen) 545, 552-53 (1862), where Bigelow, C. J., says: "The defendants, being citizens of this state, are bound by its laws. They cannot be permitted to do any acts to evade or counteract their operation, the effect of which is to deprive other citizens of rights which those laws are intended to secure. . . By interposing to prevent it, we do not interfere with the jurisdiction of courts in other states, or control the operation of foreign laws. We only assert and enforce our own authority over persons within our jurisdiction, to prevent them from making use of means by which they seek to countervail and escape the operation of our own laws, in derogation of the rights and to the wrong and injury of our own citizens." Accord: Weaver v. Alabama Great So. R. Co., 200 Ala. 432, 76 So. 364 (1917); O'Haire v. Burns, 45 Colo. 432, 101 Pac. 755 (1909); Wilson v. Josephs, 107 Ind. 490, 8 N.E. 616 (1886); Teager v. Landsley, 69 Iowa 725 (1886); Wierse v. Thomas, 145 N.C. 261, 59 S.E. 58 (1907); Bigelow v. Old Dominion Copper Mining \& Smelting Co., 74 N.J.Eq. 457, 71 Atl. 153 (1908). 